\title{
Anthobothrium altavelae sp. n. (Cestoda: Tetraphyllidea) from the spiny butterfly ray Gymnura altavela (Elasmobranchii: Gymnuridae) in Tunisia
}

\author{
Lassâd Neifar ${ }^{1}$, Louis Euzet ${ }^{2}$ and Oum Kalthoum Ben Hassine ${ }^{3}$ \\ ${ }^{1}$ Département de Biologie, Faculté des Sciences de Sfax, B.P. 802, 3038, Sfax, Tunisie; \\ ${ }^{2}$ Station Méditerranéenne de l'Environnement Littoral, Université Montpellier II, 1 Quai de la Daurade, 34200 Sète, France; \\ ${ }^{3}$ Laboratoire de Biologie et Parasitologie marines, Faculté des Sciences de Tunis, 2092, Tunis, Tunisie
}

Key words: Anthobothrium altavelae, parasite, Tetraphyllidea, spiral intestine, Gymnura altavela, Elasmobranchii

\begin{abstract}
Seven Gymnura altavela (Linnaeus, 1758) (Elasmobranchii, Myliobatiformes) caught off the Tunisian coast were examined for endoparasites during a three-year period (1995-1998). A phyllobothriid cestode new to science was found in the spiral intestine of all host specimens. The presence of a tetrabothridiate scolex, bothridia lacking an apical sucker, laciniate strobila, and possession of postvaginal testes are sufficient to place this species in the genus Anthobothrium Van Beneden, 1850. In this genus, we consider that only two species, both previously reported from carcharhiniform sharks, are valid: Anthobothrium cornucopia Van Beneden, 1850 and A. laciniatum Linton, 1890. Anthobothrium altavelae sp. n. can be distinguished from its congeners by its length, strobila morphology, and the number of testes. The taxonomic position of the species attributed to Anthobothrium parasitic in gymnurids is discussed.
\end{abstract}

During the collection of elasmobranch parasites off the Tunisian coast, we recovered numerous specimens of a phyllobothriine species from Gymnura altavela (Linnaeus, 1758). These worms represent a new species of the genus Anthobothrium Van Beneden, 1850. As reemphasised by Ruhnke (1994a) the systematics of the Phyllobothriinae have confounded cestodologists for a long time. We hope that description of this parasite of $G$. altavela may contribute to the resolution of the systematics of Phyllobothriinae.

\section{MATERIALS AND METHODS}

Cestodes were collected from the spiral intestines of seven G. altavela caught off the Tunisian coast at Bizerte $\left(37^{\circ} 30^{\prime} \mathrm{N}\right.$, $\left.9^{\circ} 50^{\prime} \mathrm{E}\right)$ and Zarzis $\left(33^{\circ} 15^{\prime} \mathrm{N}, 11^{\circ} 10^{\prime} \mathrm{E}\right)$. Fish were dissected as soon as possible after capture. Each specimen was opened with a circumventral incision. The spiral intestine was tied at the level of rectum anterior to the rectal gland. The gut was cut posteriorly to this gland and anterior to the pyloric sphincter. Each spiral intestine was immediately opened in seawater or injected with an $8 \%$ formalin solution by insertion of a syringe into the lumen of the pylorus. The pyloric end was then ligated and after tying up these intestines were immerged in 5\% formalin. Living and fixed tapeworms were removed from each chamber, washed with filtered seawater and studied slightly flattened between a slide and a coverslip. Individual worms were fixed with $70 \%$ ethanol, $5 \%$ neutral formalin and Bouin-Hollande liquid. Specimens were stained with Semichon's acetic carmine or haematoxylin. Following dehydration in ethanol, specimens were cleared in clove oil and mounted in Canada balsam. Cross-sections and frontal- sections $10 \mu \mathrm{m}$ thick were prepared according to methods given in Chatton (1923).

Illustrations and measurements were made with the aid of a Leitz microscope drawing tube. All measurements are given in micrometres unless stated otherwise. The arithmetic means are given in the text, followed by the standard deviation, range in parentheses and number of observations (n). We use the terms proximal and distal surface for each side of bothridia as proposed by Ruhnke (1994a). Specimens from Gymnura altavela were compared with $A$. cornucopia Van Beneden, 1850 from Galeorhinus galeus and A. laciniatum var. brevicolle Linton, 1890 from Prionace glauca (personal collection of L. Euzet). Systematics of the host species is consistent with that given in Compagno (1999).

\section{RESULTS}

Anthobothrium altavelae sp. $\mathrm{n}$.

Figs. 1-4

Description and measurements based on 25 complete flattened specimens, 30 free proglottides and 2 crosssectioned worms.

Phyllobothriinae. Strobila craspedote, laciniated, euapolytic, $5.9 \mathrm{~mm} \pm 400(4-8.5 \mathrm{~mm})(\mathrm{n}=25)$ long. Greatest width $423 \pm 32(280-550)(\mathrm{n}=25)$ at the terminal segment. Number of segments $25 \pm 2$ (19-34) $(n=25)$ per worm. Scolex composed of 4 pedunculate, spoon-shaped bothridia, margins entire without suckers or loculi. Bothridia $325 \pm 19(200-400)(n=25)$ long by $224 \pm 12(180-300)(n=22)$ wide. Distal surface of bothridia concave, with inner hemi-circular muscular band $118 \pm 6(90-140)$ in diameter $(n=25)$, proximal surfaces with spinitriches. Cephalic peduncle present, 

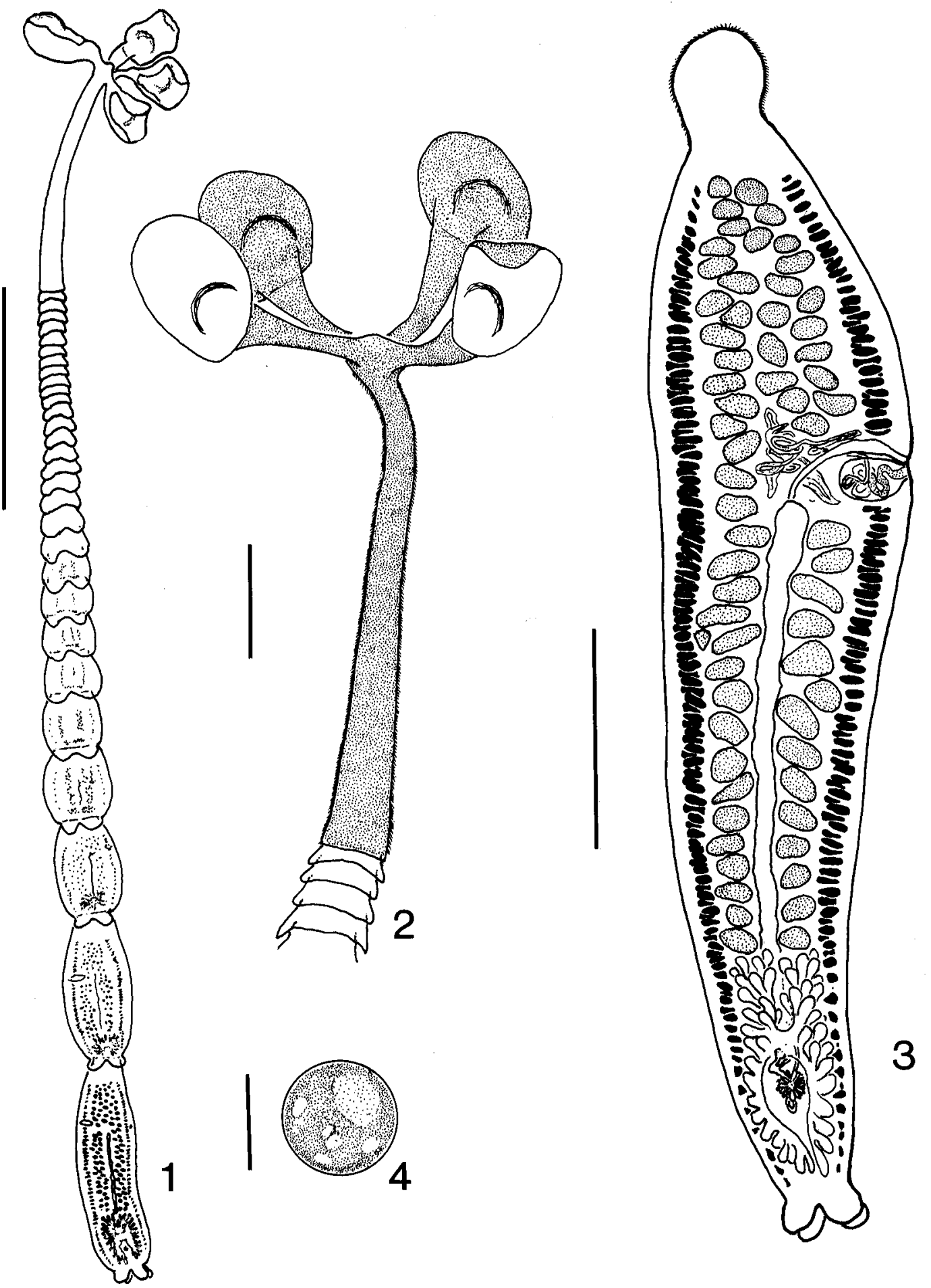

Figs. 1-4. Anthobothrium altavelae sp. n. from Gymnura altavela. Fig. 1. Whole worm, ventral view. Fig. 2. Scolex with long cephalic peduncle and laciniate first segments. Fig. 3. Detached mature proglottis. Fig. 4. Egg. Scale bars: Figs. 1, $3=1 \mathrm{~mm}$; Fig. $2=250 \mu \mathrm{m}$; Fig. $4=15 \mu \mathrm{m}$.

$745 \pm 75(400-1200)(\mathrm{n}=24)$ long by $150 \pm 7(140-$ $160)(\mathrm{n}=24)$ wide, covered with spinitriches. Immature segments wider than long, $53 \pm 3(40-60)(\mathrm{n}=25)$ long by $179 \pm 10(150-230)(\mathrm{n}=25)$ wide. Mature segments $895 \pm 38(725-915)(\mathrm{n}=25)$ long by $415 \pm 38(270$ -
540) $(\mathrm{n}=25)$ wide. Free proglottides $1.9 \mathrm{~mm} \pm 112$ $(1.4-3 \mathrm{~mm})$ long by $856 \pm 47(700-1000)(\mathrm{n}=30)$ wide. Anterior part of detached proglottides globular with microtriches. 
Testes $72 \pm 4(59-94)(\mathrm{n}=25)$ in total number, $37 \pm 2$ $(32-48)(\mathrm{n}=25)$ antiporal, $14 \pm 2(10-20)(\mathrm{n}=25)$ anterior and $21 \pm 1(17-26)(\mathrm{n}=25)$ posterior to vagina in poral side. Testes $42 \pm 4(25-60)(\mathrm{n}=25)$ long by 24 $\pm 2(15-35)(\mathrm{n}=25)$ wide, posterior widest. Cirrus sac ovoid, $130 \pm 7(100-160)(\mathrm{n}=25)$ long by $80 \pm 5(70-$ $105)(\mathrm{n}=25)$ wide, containing coiled cirrus armed with minute spinitriches. Genital pores irregularly alternate, $32 \pm 2 \%(25-38 \%)$ of segment length from anterior end. Vagina median, extending from anterior margin of cirrus sac to ovary. Ovary H-shaped, $248 \pm 27$ (150350) $(\mathrm{n}=25)$ long, bilobed in cross-section. Mehlis' gland poste-rior to ovarian isthmus, $61 \pm 6$ (50-100) (n $=25$ ) in diameter. Two lateral bands of vitelline follicles extend-ing entire length of segments except at the level of cirrus sac. Uterus ventral extending along median line of pro-glottis from ovary to slightly posterior to cirrus sac.

Eggs round, $16 \pm 7(15-18)(n=5)$ in diameter, in gravid free segments.

Ty p e host: Gymnura altavela (Linnaeus, 1758).

T y p e 1 o c a 1 i t y : Bizerte (Tunisia) $\left(37^{\circ} 30^{\prime} \mathrm{N}, 9^{\circ} 50^{\prime} \mathrm{E}\right)$.

O the r 1 o c a 1 it y: Zarzis (Tunisia) $\left(33^{\circ} 15^{\prime} \mathrm{N}, 11^{\circ} 10^{\prime} \mathrm{E}\right)$.

Mi c r o hab it a t: Spiral intestine.

P r e v a l e n c e : $100 \%$ (7 G. altavela examined).

$\mathrm{T}$ y $\mathrm{p}$ e $\mathrm{m}$ a t e r i a 1: Holotype in Muséum National d'Histoire Naturelle, Paris, MNHN 52 HG 162 C-IX; 3 paratypes, MNHN 52 HG 163 C-IX and MNHN 164 C-IX; 3 paratypes in the Natural History Museum, London, BMNH 2002.5.7.7-8.; and 3 paratypes in the Institute of Parasitology, Academy of Sciences of the Czech Republic, České Budějovice (Coll. No HC-369). Other paratypes in collection of the senior author.

E t y m o lo g y: The specific epithet altavelae refers to the name of the host Gymnura altavela.

Remarks. Anthobothrium altavelae is similar to A. laciniatum var. longicolle Linton, 1890 , but can be distinguished from that species in the total length (4-8.5 $\mathrm{mm} v s 6-25 \mathrm{~mm}$ ) and by the number of segments per worm (19-34 vs 60-120).

Hemi-circular musculature in fixed specimens describes a pseudo-sucker in the central distal surface of the bothrida. This structure was described by Euzet (1959) for A. laciniatum var. brevicolle from Prionace glauca and again by Ruhnke (1994b) in Paraorygmatobothrium barberi Ruhnke, 1994 from Triakis semifasciata. The condition in Anthobothrium and Paraorygmatobothrium are not homologous.

\section{DISCUSSION}

Euzet (1994) gave the following diagnosis for Anthobothrium: "Scolex with four bothridia, pedunculate with a simple edge. Accessory sucker absent. Sometimes one central muscular sucker. Strobila craspedote, laciniated, euapolytic. Genital pores irregularly alternating. Testes numerous, postvaginal testes present on poral side. Ovary posterior. Vitelline follicles lateral".

The central structure in the bothridia is not a true sucker but a depression resulting from the presence of hemi-circular muscular band. We propose to change the diagnosis of the genus to indicate this structure as follows: Sometimes one hemi-circular muscular band (pseudo-sucker) present in centre of each bothridium.

Schmidt (1986) listed 23 species in the genus Anthobothrium. Some of them, in particular those parasitic in batoids, do not correspond to the above diagnosis. The generic placement of those species must be reconsidered.

Among these species allocated to Anthobothrium, two are parasites of gymnurid stingrays, i.e. Anthobothrium pteroplateae Yamaguti, 1952 and A. bifidum Yamaguti, 1952, parasites of Pteroplatea japonica (=Gymnura japonica) and Pteroplatea micrura (=Gymnura micrura), respectively. These two species do not have pedunculate bothridia, segments are not laciniate, and they lack postvaginal testes. Their morphology is not consistent with the diagnosis of the genus Anthobothrium. They must be placed in another genus of the Phyllobothriidae.

In the genus Anthobothrium we recognise two species: the type $A$. cornucopia Van Beneden, 1850 from Galeorhinus galeus, and A. laciniatum Linton, 1890 from various carcharhinid sharks. Anthobothrium laciniatum is taxonomically problematic because Linton (1890) recognised the presence of the two varieties: $A$. laciniatum brevicolle and $A$. laciniatum longicolle. We think that the two varieties may represent different species. Our suspicion seems to be confirmed by the fact that Anthobothrium laciniatum described by Yamaguti (1934) from Scoliodon walbeehmi differs in size (16 mm vs 25-30 mm) and number of testes (140180 vs 110-140) compared to $A$. laciniatum from Prionace glauca such as described by Riser (1955) in Californian coastal waters and by Euzet (1959) at Sète (Mediterra-nean Sea). Considering the number of hosts reported by Linton (1924), a comparative study of the genus Antho-bothrium in Carcharhinidae is necessary. Anthobothrium laciniatum likely represents a complex of species.

The species of Anthobothrium are normally parasites of Carcharhiniformes. The presence of $A$. altavelae in $G$. altavela (Myliobatiformes) may be explained by a phenomenon of overlapping dietary prey. We found in the stomach of some $G$. altavela examined numerous clupeid fish, which are also consumed by Carcharhiniformes. Larvae of the "Scolex pleuronectis" type, which are plerocercoids of Tetraphyllidea, were reported from the intestine of various clupeid species, for instance Sardina pilchardus (Walbaum) (Euzet 1959). 
CHATTON E. 1923: Technique de double inclusion à l'agar et à la paraffine pour microtomie, avec orientation ou en masse, d'objets très petits. C. R. Séances. Soc. Biol. 75: 199-202.

COMPAGNO L.J.V. 1999: Checklist of living Elasmobranchs. Appendix. In: W.C. Hamlett (Ed.), Sharks, Skates and Rays. The Biology of Elasmobranch Fishes. Johns Hopkins University Press, Baltimore and London, pp. 471-498.

EUZET L. 1959: Recherches sur les Cestodes Tétraphyllides des Sélaciens des côtes de France. Thèse (1956), Faculté des Sciences, Université de Montpellier, 263 pp.

EUZET L. 1994: Order Tetraphyllidea. In: L.F. Khalil, A. Jones and R.A. Bray (Eds.), Keys to the Cestode Parasites of Vertebrates. CAB International, Wallingford, pp. 149194.

LINTON E. 1890: Notes on Entozoa of marine fishes of New England. Part II. Annual Report of the United States
Commissioner of Fish and Fisheries for 1887, 15: 718899.

LINTON E. 1924: Notes on cestode parasites of sharks and skates. Proc. U.S. Natl. Mus. 64, 2511: 1-114.

RISER N.W. 1955: Studies on cestode parasites of sharks and skates. J. Tennessee Acad. Sci. 30: 265-311.

RUHNKE T.R. 1994a: Resurrection of Anthocephalum (Cestoda: Tetraphyllidea) and taxonomic information on five proposed members. Syst. Parasitol. 29: 159-176.

RUHNKE T.R. 1994b: Paraorygmatobothrium barberi n. g., n. sp. (Cestoda: Tetraphyllidea) with amended descriptions of two species transferred to the genus. Syst. Parasitol. 28: 65-79.

SCHMIDT G.D. 1986: Order Tetraphyllidea. In: G.D. Schmidt (Ed.), CRC Handbook of Tapeworm Identification. CRC Press, Boca Raton, USA, pp. 131-164.

YAMAGUTI S. 1934: Studies on the helminth fauna of Japan. Part 4 - Cestodes of fishes. Jpn. J. Zool. 6: 1-112. 